\title{
Peatlands as a model system for exploring and reconciling Quaternary chronologies
}

\author{
Maarten Blaauw ${ }^{1}$, J.A. Christen ${ }^{2}$ and D. Mauquoy 3 \\ 'School of Geography, Archaeology and Palaeoecology, Queen's University Belfast, UK; maarten.blaauw@qub.ac.uk \\ ${ }^{2}$ Centre for Mathematical Research, Guanajuato, Mexico; ${ }^{3}$ Geography and Environment, University of Aberdeen, UK
}

\section{Recent developments in statistical techniques enable quantitative assessment of the chronological reliability of radiocarbon-dated peatland profiles.}

The use of peatlands as datable archives of past climate and environmental change goes back for more than a century. Early age estimates were based on correlating peat stratigraphy within and among sites, assuming that specific horizons represented regionally synchronous events (Fig. 1). Peat layers with different vegetation or degrees of decomposition were thought to reflect past changes in climate (e.g., cooler, warmer, drier or wetter; von Post, 1946). The boundaries between these layers were then linked to the ages of environmental changes as inferred from independently dated archives (e.g., varve chronologies, links between pollen and archeological phases). These early peatland age-models were relative and imprecise, owing to their dependence on inferred synchrony of layers with imprecisely dated events in other archives.

\section{Radiocarbon dating}

The development of radiocarbon dating in the 1950s led to estimation of absolute ages for organic material such as peat. While deposits such as soils, oceans or lakes often contain little and/or heterogeneous carbon (e.g., blends of stable and labile organic components, hard water effects through carbonate seepage from surrounding bedrock), carbon is very abundant in peat and is mostly derived from the local, in situ, vegetation. As the living, contemporary plant matter on the bog surface becomes overgrown by new vegetation, cool, wet and acidic conditions combined with high decay-resistance of Sphagnum tissues in the accumulating sub-fossil organic matter, ensure slow decomposition. Therefore, most of the carbon in a slice of peat will generally have ${ }^{14} \mathrm{C}$ ages corresponding to the time at which that slice was accumulating at the original bog surface. Above-ground plant remains such as moss, seeds, stems, leaves or pollen are generally preferred over bulk material, because such selected remains will be contemporaneous with the depth of the peat, while bulk dates can contain a mix of contemporaneous and older or younger material (e.g., rootlets).

For recent peat deposits, additional dating techniques are available (e.g.,

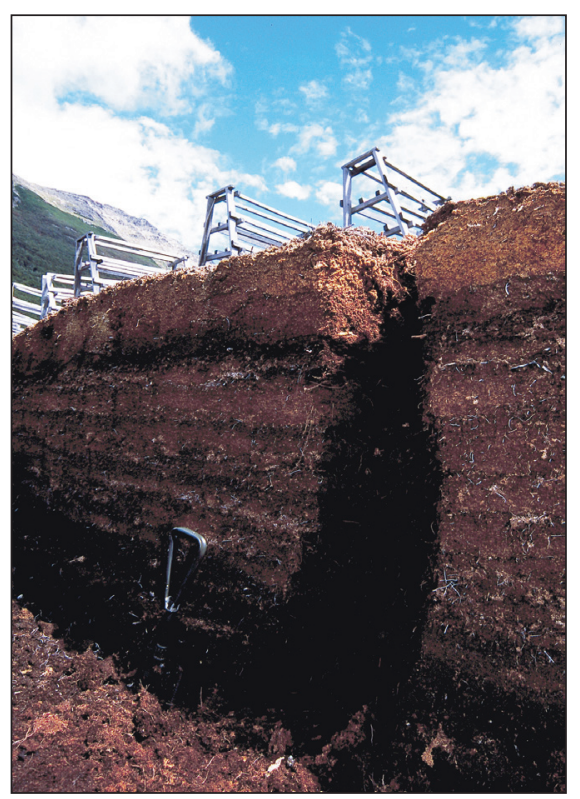

Figure 1: Section of a Sphagnum magellanicum raised peat bog in Tierra del Fuego. Note the 'layer-cake'stratigraphy where the changes from dark to humified peat can be traced for $\sim 50 \mathrm{~m}$.

bomb-peak ${ }^{14} \mathrm{C}$ dating for peat younger than c. AD 1960 (van der Linden et al., 2008), and lead dating for peat younger than c. AD 1850 (Turetsky et al., 2004)). Moreover, well-dated and geochemically identifiable volcanic ash (tephra) layers can provide valuable dating points, and can be used to align proxy archives between regions (Pilcher et al., 1995).

\section{Age-depth modeling}

Even though most peat contains abundant datable organic matter, it can be difficult to select sufficient above-ground macroremains from highly degraded peat. Moreover, selection and cleaning of material for ${ }^{14} \mathrm{C}$ dating can be time-consuming and ${ }^{14} \mathrm{C}$ dates are expensive. Therefore, generally only a few sample depths in a peat profile are dated. Moreover, ${ }^{14} \mathrm{C}$ dates themselves can show considerable scatter (Scott, 2007), and calibrated distributions can be irregular and wide. In order to provide calendar ages for each (dated or undated) depth of a core, some sort of modeling is needed. Each model has its specific advantages and limitations, and choosing a particular type of age-depth model will yield a distinct age-depth relationship (Bennett and Fuller, 2002; Telford et al., 2004).
A widely used basic age-depth model is linear interpolation between the dated levels (Bennett, 1994). This method assumes abrupt accumulation rate changes between each dated level, which for peat bogs seems an unrealistic scenario. Agedepth models that are considered more ecologically plausible and that take into account likely modes of peat accumulation, include (1) linear accumulation (over limited time intervals; Belyea and Clymo, 2001; Blaauw and Christen, 2005), (2) concave curves (through continuing decomposition of fossil matter in the peat deposit; Yu et al., 2001), (3) convex curves (with deposits slowing down their accumulation when close to a height limit; Belyea and Baird, 2006), and (4) Bayesian models that can include prior information on stratigraphy, accumulation rate and variability, and/or detect outlying dates (e.g., Blaauw and Christen, 2005; Bronk Ramsey, 2008; Blaauw et al., in prep.).

Confidence intervals of calibrated radiocarbon ages (Reimer et al., 2009) are often considerably larger than the original ${ }^{14} \mathrm{C}$ measurement uncertainties, especially during wiggles or plateaux in the calibration curve. For example, a date of $2.45 \pm 20$ ${ }^{14} \mathrm{C}$ ka BP (i.e., on the Hallstatt plateau) obtains a $95 \%$ range of 440 years on the calendar scale. Therefore, many ${ }^{14} \mathrm{C}$-dated peat chronologies possess centennialscale uncertainties. However, through matching dense series of ${ }^{14} \mathrm{C}$ dates to wiggles in the calibration curve (radiocarbon wiggle-match dating; van Geel and Mook, 1989), much higher precision chronologies can often be obtained (Christen et al., 1995; Kilian et al., 1995; 2000; Mauquoy et al., 2002; Blaauw et al., 2003; Blaauw and Christen, 2005; Chambers et al., 2007; see also van Geel and Mauquoy, this issue). Wiggle-matching performs best where the calibration curve has pronounced wiggles, often resulting in decadal-scale precision during the Subboreal/Subatlantic transition (Kilian et al., 2000) or during the Little Ice Age (Mauquoy et al., 2002; Fig. 2).

\section{Multi-site comparisons}

Until recently, most comparisons of proxy reconstructions between cores, sites and regions have been visual and rather sub- 
a)

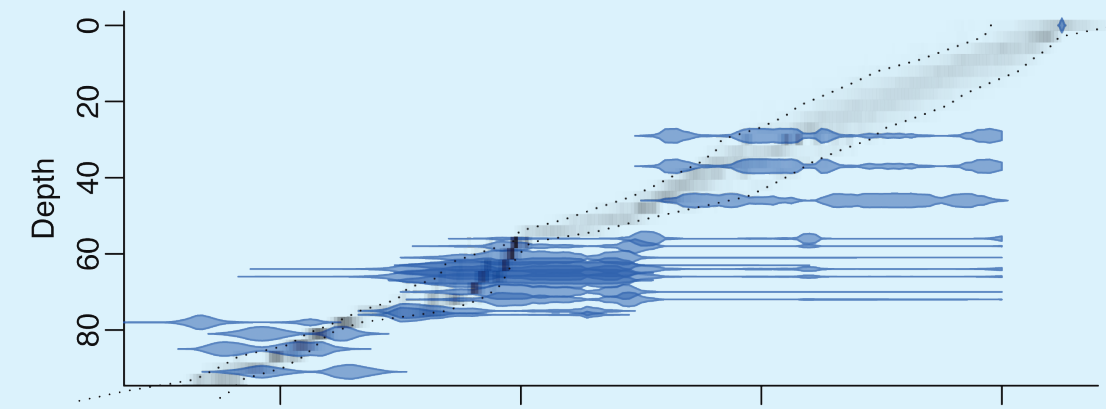

b)

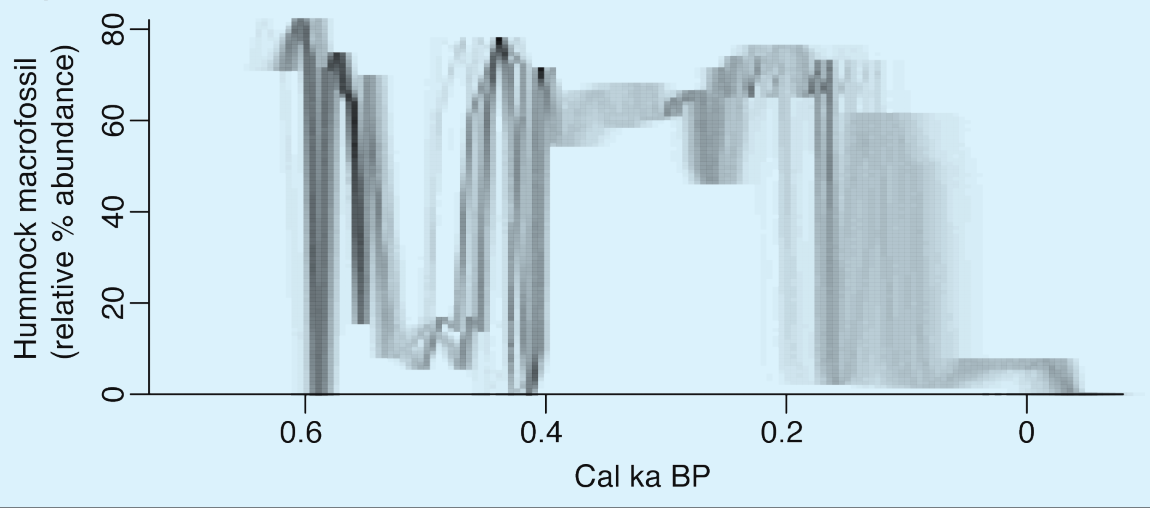

Figure 2: a) Bayesian age-depth model of a late Holocene peat core from Lille Vildmose in Denmark (Mauquoy et al., 2002). The model consists of many small sections of linear accumulation, with a degree of memory between neighboring sections (Blaauw et al., in prep.). Blue shapes are calibrated probability distributions of 17 radiocarbon dates (together with the core's surface, which is set at an age of AD 2000 \pm 1 ). Gray shapes show the posterior probability distribution of a) the age-depth model and $\boldsymbol{b}$ ) hummock macrofossil proxies (relative \% abundance of Sphagnum capillifolium). Dotted lines in (a) indicate 95\% confidence range. Abundant hummock proxies indicate relatively dry conditions on the bog's surface. Precisely and reliably dated core sections are plotted dark and narrow, while wide grey smudges indicate chronologically uncertain depths (Blaauw et al., 2007).

jective. Proxy curves from multiple sites are generally plotted on either independent or tuned timescales, after which synchroneity, leads or lags between sites are inferred through "eye-balling" or by drawing subjective lines connecting events be- tween sites. Recently developed statistical alternatives however can quantitatively assess leads and lags (Parnell et al., 2008) or synchroneity (Blaauw et al., 2007, 2010a) between independently dated proxy archives. A recent example is provided by

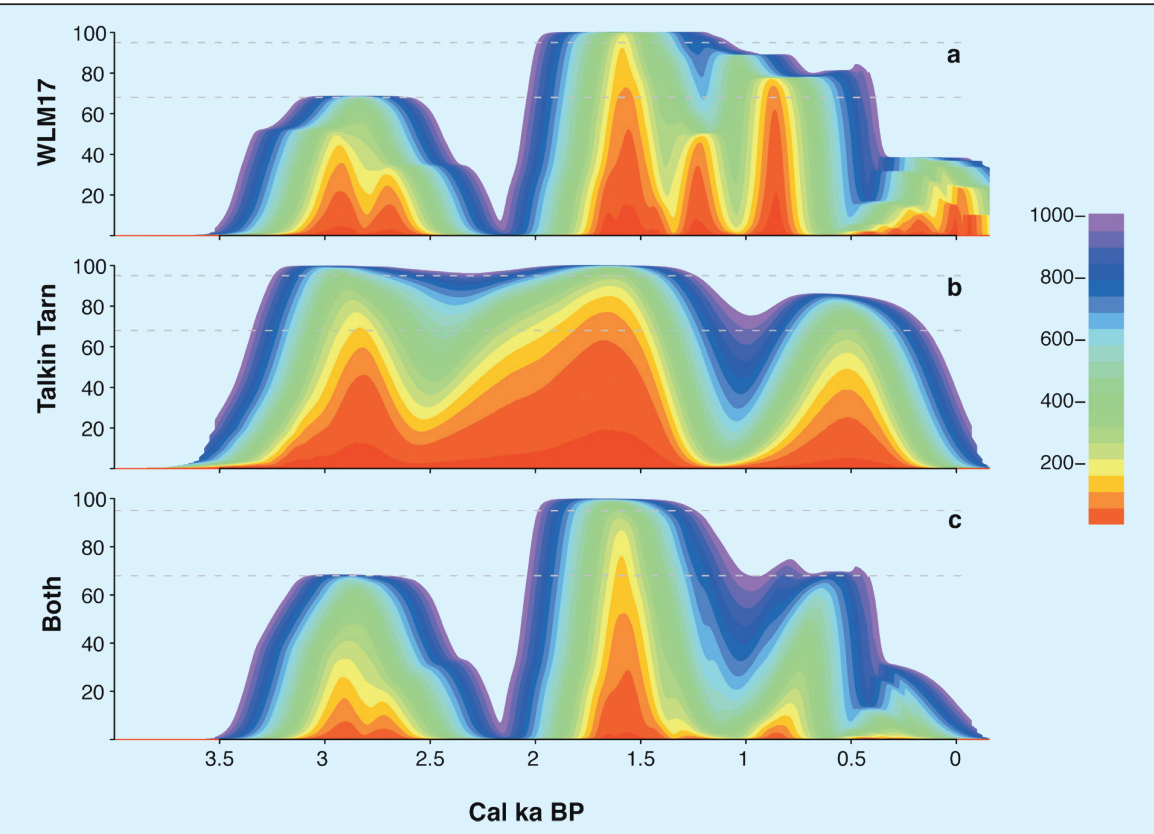

Figure 3: Events of increased moisture in two independently dated adjacent sites in northern England (Barber and Langdon, 2007; Charman et al., 2009); a) core WLM17 sampled from peat bog Walton Moss; b) lake sediment core from nearby Talkin Tarn. Probabilities of increased moisture in each of the sites during a period of time were calculated using a moving time-window approach (Blaauw et al., 2007, 2010) with window sizes of 10 to 1000 years, shown as rainbow colors in the probability histograms. c) shows the probabilities of simultaneous events between WLM17 and Talkin Tarn within specified time-windows. Dotted lines indicate 68\% and 95\% confidence levels, respectively. Taken from Charman et al. (2009) with permission from Elsevier.
Charman et al. (2009), who quantify the synchroneity of climate events between a peat bog and an adjacent lake in northern England (Fig. 3). Importantly, the degree of synchroneity of proxy events between archives depends on the chronological resolution of these archives. If chronological uncertainties of the archives are, for example, at the centennial scale, these archives cannot be used to answer questions at decadal resolution (Blaauw et al., 2007).

A wealth of paleoecological data has now been obtained from peat archives across the globe, and one of the remaining challenges is how to interpret these data in terms of quantitative past climate and environmental changes. By applying novel numerical methods to peatland chronologies, more realistic estimates can now be obtained for the spatio-temporal pattern of past environmental events (e.g., regional differences). Novel numerical methods are also being developed to assess the reliability of proxy records as quantitative archives of past climate and environmental changes. For example, Blaauw et al. (2010b) suggest that we cannot assume that every proxy change is necessarily forced by a single traceable external factor such as climate change (e.g., Blaauw et al., 2010a). Hopefully, such numerical methods will eventually enhance our understanding of the possibilities and limitations of peat archives for reconstructing past environmental change.

\section{References}

Blaauw, M. and Christen, J.A., 2005: Radiocarbon peat chronologies and environmental change, Applied Statistics, 54: 805-816.

Blaauw, M., Christen, J.A., Mauquoy, D., van der Plicht, J. and Bennett, K.D., 2007: Testing the timing of radiocarbon-dated events between proxy archives, The Holocene, 17: 283-288.

Blaauw, M., Bennett, K.D. and Christen, J.A., 2010b: Random walk simulations of fossil proxy data, The Holocene.

Charman, D., Barber, K., Blaauw, M., Langdon, P., Mauquoy, D., Daley, T., Hughes, P. and Karofeld, E., 2009: Climate drivers for peatland palaeoclimate records, Quaternary Science Reviews, 28: 18111819.

Turetsky, M.R., Manning, S. and Wieder, R.K., 2004: Dating recent peat deposits, Wetlands, 24: 324-356.

For full references please consult:

http://www.pages-igbp.org/products/newsletters/ref2010_1.htm 


\section{Blaauw, J. Andrés Christen and D. Mauquoy}

Barber, K.E. and Langdon, P.G., 2007: What drives the peat-based palaeoclimate record? A critical test using multi-proxy climate records from northern Britain, Quaternary Science Reviews, 26: 3318-3327.

Belyea, L.R. and Clymo, R.S., 2001: Feedback control of the rate of peat formation, Proceedings of the Royal Society of London: Biological Sciences, 268: 1315-1321.

Belyea, L.R. and Baird, A.J., 2006: Beyond the "limits to peat bog growth": cross-scale feedback in peatland development, Ecological Monographs, 76: 299-322.

Bennett, K.D., 1994: Confidence intervals for age estimates and deposition times in lateQuaternary sediment sequences, The Holocene, 4: 337-348.

Bennett, K.D. and Fuller, J.L., 2002: Determining the age of the mid-Holocene Tsuga canadensis (hemlock) decline, eastern North America, The Holocene, 12: 421-429.

Blaauw, M. and Christen, J.A., 2005: Radiocarbon peat chronologies and environmental change, Applied Statistics, 54: 805-816.

Blaauw, M., Heuvelink, G.B.M., Mauquoy, D., van der Plicht, J. and van Geel, B., 2003: A numerical approach to ${ }^{14} \mathrm{C}$ wiggle-match dating of organic deposits: best fits and confidence intervals, Quaternary Science Reviews, 22: 1485-1500.

Blaauw, M., Christen, J.A., Mauquoy, D., van der Plicht, J. and Bennett, K.D., 2007: Testing the timing of radiocarbon-dated events between proxy archives, The Holocene, 17: 283288.

Blaauw, M., Wohlfarth, B., Christen, J.A., Ampel, L., Veres, D., Hughen, K.A., Preusser, F. and Svensson, A., 2010a: Were last glacial climate events simultaneous between Greenland and France? A quantitative comparison using non-tuned chronologies, Journal of Quaternary Science, 25: 387-394.

Blaauw, M., Bennett, K.D., Christen, J.A., 2010b: Random walk simulations of fossil proxy data, The Holocene, doi:10.1177/0959683609355180.

Blaauw, M., Christen, J.A., Pérez, S.E., in preparation: Flexible palaeoclimate age-depth models using an autoregressive gamma process.

Bronk Ramsey, C., 2008: Deposition models for chronological records, Quaternary Science Reviews, 27: 42-60.

Chambers, F.M., Mauquoy, D., Brain, S.A., Blaauw, M. and Daniell, J.R.G., 2007: Globally synchronous climate change 2800 years ago: Proxy data from peat in South America, Earth and Planetary Science Letters, 253: 439-444.

Charman, D., Barber, K., Blaauw, M., Langdon, P., Mauquoy, D., Daley, T., Hughes, P. and Karofeld, E., 2009: Climate drivers for peatland palaeoclimate records, Quaternary Science Reviews, 28: 1811-1819.

Christen, J.A., Clymo, D. and Litton, C.D., 1995: A Bayesian approach to the use of ${ }^{14} \mathrm{C}$ dates in the estimation of the age of peat, Radiocarbon, 37: 431-442.

Kilian, M.R., van der Plicht, J. and van Geel, B., 1995: Dating raised bogs: new aspects of AMS ${ }^{14} \mathrm{C}$ wiggle matching, a reservoir effect and climatic change, Quaternary Science Reviews, 14: 959-966.

Kilian, M.R., van Geel, B. and van der Plicht, J., 2000: ${ }^{14} \mathrm{C}$ AMS wiggle matching of raised bog deposits and models of peat accumulation, Quaternary Science Reviews, 19: 10111033.

Mauquoy, D., van Geel, B., Blaauw, M. and van der Plicht, J., 2002: Evidence from Northwest European bogs shows 'Little Ice Age' climatic changes driven by changes in solar activity, The Holocene, 12: 1-6.

Parnell, A.C., Haslett, J., Allen, J.R.M., Buck, C.E. and Huntley, B., 2008: A flexible approach to assessing synchroneity of past events using Bayesian reconstructions of sedimentation history, Quaternary Science Reviews, 27: 1872-1885.

Pilcher, J.R., Hall, V.A. and McCormac, F.G., 1995: Dates of Holocene Icelandic volcanic eruptions from tephra layers in Irish peats, The Holocene, 5: 103-110.

Reimer, P.J. et al., 2009: IntCal09 and Marine09 radiocarbon age calibration curves, 0 50,000 years cal BP, Radiocarbon, 51: 1111-1150. 
Scott, E.M., 2007: Radiocarbon dating: sources of error. In: Elias, S.A. (Ed), Encyclopedia of Quaternary Science, Elsevier, Amsterdam: 2918-23.

Telford, R.J., Heegaard, E. and Birks, H.J.B., 2004: All age-depth models are wrong: but how badly? Quaternary Science Reviews, 23: 1-5.

Turetsky, M.R., Manning, S. and Wieder, R.K., 2004: Dating recent peat deposits, Wetlands, 24: 324-356.

van der Linden, M., Vickery, E., Charman, D.J. and van Geel, B., 2008: Effects of human impact and climate change during the last 350 years recorded in a Swedish raised bog deposit, Palaeogeography, Palaeoclimatology, Palaeoecology, 262: 1-31.

van Geel, B. and Mook, W.G., 1989: High-resolution ${ }^{14} \mathrm{C}$ dating of organic deposits using natural atmospheric $14 \mathrm{C}$ variations, Radiocarbon, 31, 151-155.

Van Geel, B. and Mauquoy, 2010: Peatland records of solar activity, PAGES news, 18(1).

von Post, L., 1946: The prospect for pollen analysis in the study of the Earth's climatic history, New Phytologist, 45: 193-217.

Yu, Z., Campbell, I.D., Vitt, D.H. and Apps, M.J., 2001: Modelling long-term peatland dynamics. I. Concepts, review, and proposed design, Ecological modelling, 145: 197210 . 